\title{
8
}

\section{Fiji elections and the youth vote-token or active citizenship?}

\author{
Patrick Vakaoti
}

\section{Introduction}

The 2013 Constitution, particularly its provision reducing the voting age to 18 years, helped propel young people into the political limelight. Traditionally and historically, young people in Fiji have often been left out of structures of political decision-making at the local and national levels (Vakaoti 2013). During the September 2014 general elections, young people between the ages of 18 to 35 years constituted about 40 per cent of the electorate (Round 2014b). As a result, political commentators asserted that young people held the balance of power. Given the absence of relevant voter information, the influence of young voters on the election outcome is difficult to establish. This is complicated by the fact that young people are not a homogenous group. It is evident that the majority of registered young voters exercised their right and voted in the 17 September 2014 elections, embracing the democratic opportunity to elect parliamentary representatives.

Given the dearth of published sources on young people's democratic participation, specifically voting in Fiji, the discussion in this chapter uses as a backdrop the Citizen's Constitutional Forum's (CCF) 
2014 report, 'Young People and Democratic Participation in Fiji' (Vakaoti 2014). The report, hereafter referred to as the CCF Youth Democratic Participation survey, uses the concept of generation to explore young people's understanding of democratic participation and the influences on their political involvement in the lead-up to the 17 September general elections. Of particular interest for this chapter are the findings of the report relating to young people and electoral and constitutional reform, which looked specifically at young people's responses to questions on political parties, politics and voting.

This chapter is divided into five sections. The first section explores the rationale for reducing the voting age to 18 years and makes the point that voting is only one part of active citizenship. The second section looks at the support provided to young people by the government, political parties, civil society organisations (CSOs) and the media. The third section considers the impact of the youth vote, with the fourth section suggesting ways youth stakeholders discussed in section two can support young people's democratic participation that extends beyond voting. The chapter concludes with a caution to stakeholders, particularly the government, about its promise to accord young people equal civil and political rights.

\section{Engaging young people: 2013 Constitution}

The reduction of the voting age from 21 to 18 years was one of the nonnegotiable principles ${ }^{1}$ of the 2013 Constitution. This decision appeared to align with the minimum voting age of 18 years in countries like Australia, New Zealand and the United Kingdom. ${ }^{2}$ In Fiji, reasons for the reduction in the voting age are vaguely expressed in government statements such as 'Government has recognized the need to empower and involve youths in decision making and has reduced the voting age to 18 [years]' (Fiji Government Online 2014) and 'Fiji's Constitution ... provides for greater civil and political rights to youths through reduction of the voting age from 21 to 18 years ensuring their say in

\footnotetext{
1 Other non-negotiable principles and values include a common and equal citizenry; a secular state; the removal of systematic corruption; an independent judiciary; elimination of discrimination; good and transparent governance; social justice; one person, one vote, one value; the elimination of ethnic voting and proportional representation.

2 This criteria is assessed with other criteria, particularly that around residency status.
} 
the political life of the nation' (Fiji Government Online 2013). It could be argued that this position reflects the government's mantra of 'a common and equal citizenry, a common identity and a level playing field on which every citizen can excel' (Online Editor 2014).

The reduction in the voting age was received with mixed reactions. Political parties like the Fiji Labour Party (FLP), People's Democratic Party (PDP) and the Social Liberal Democratic Party (SODELPA) welcomed this change (Gibson 2014b; Baines 2013; Round 2014a). Fifty-four per cent of respondents in the CCF Youth Democratic Participation survey also supported this change, with the view that young people at 18 years are mature enough to vote. On the other hand, 41 per cent of young people in the survey believed that the voting age should be retained at 21 years. The main contention was that young people were not consulted about this decision. According to Vakaoti (2014, p. 37) focus group participants in the survey argued that:

young people are being manipulated, a government tactic to generate support given its knowledge about the significance of the youth vote ... [Focus group participants] in Nadi argued that the government was drawing from developed countries where many young people are independent. They added that the Fiji situation is different as many young people continue to depend on their parents who at the same time can influence a young person's voting behavior.

Despite this contention, young people actively and excitedly took to the polls. This was evident in the CCF Youth Democratic Participation survey, where 67 per cent of participants were identified as having registered to vote, 61 per cent of whom intended to vote (Vakaoti 2014). This suggests that many young people were excited by the prospect of voting, many for the first time (Ewart 2014). The nature of young people's political participation in the lead-up to the elections can be examined based on their engagement in political party campaigning, CSOs voter awareness and training and media engagement. 


\section{Young people and the elections: Preparedness and support}

According to Esser (2007, p. 1195), 'voting is still the most basic and arguably most important democratic act ... it is an essential part of political socialization, a cornerstone of democratic stability ...'. The importance of voting assumes that as a result of preparedness and education, voters will make an informed decision on Election Day. In Fiji's case, this was questionable. The CCF Youth Democratic Participation survey identified that only 29 per cent of young people felt they 'most probably' understood the voting system, whilst 40 per cent stated they had 'no understanding' at all. This limited understanding raises questions about young people having the ability to make informed choices. The majority of those who felt they had 'no understanding' were between the ages of 17 and 23 years and were first-time voters (Vakaoti 2014). This lack of understanding and awareness demonstrates the underpreparedness of young voters. This is of concern because it was considered that the young people's votes held the 'balance of power'.

In the lead-up to the elections the government, through the Fiji Elections Office (FEO), CSOs, political parties and the media, engaged in voter education and awareness. This section discusses activities directed at young people by the various stakeholders.

\section{Ministry of Youth and Sports and youth voter awareness}

The government's role in supporting young and first-time voters was restricted to awareness of the electoral process. Whilst the Ministry of Youth and Sports pledged to support young voters, its assistance was guided by what was provided by the FEO (Vukailagi 2014a). The FEO was commended for this role and its conduct of the elections resulted in the Multinational Observer Group endorsing the polls as being credible (Radio New Zealand International 2014). In June 2014, the government, through the Ministry of Youth and Sports, convened a youth conference for over 500 young people from across Fiji. Participants discussed 'issues relating to health, the environment, sports and human rights' (Fiji One 2014). It is unclear whether, 
even if the intention was to have a multiplier effect, gatherings such as this are enough to assist young people critically engage with issues that affect their lives.

\section{Political parties: Attracting the youth vote}

Political parties and, particularly, independent candidate Roshika $\mathrm{Deo}^{3}$ were actively seen to include young people in the election process. The National Federation Party (NFP), hosted three youthspecific mini conferences and a national conference to deliberate on issues to be considered in the party manifesto (Vukailagi 2014b). In addition, the party's youth wing president was a member of the party's management board. The party also fielded young candidates in the general elections. The FLP, despite its historical rivalry with the NFP, did not appear to have an active engagement with young people; its party president, Mahendra Chaudhry, was also the 'youth' spokesperson (Anthony 2014). However, the FLP nominated Laisa Bale as its official youth candidate.

The SODELPA, although dominated by seasoned Taukei politicians and adults, courted young supporters. The SODELPA Youth Council president expressed the following view: 'we feel that all political parties have started working with young people ... that's an important shift in terms of party politics and it's important that they incorporate young people into their work' (Tokalau 2014). The involvement of young people in the SODELPA party, either as volunteers and campaigners or as executive members, was magnified because of the use of social media. The SODELPA National Youth Council Forum (SODELPA Youth) manages a Facebook page ${ }^{4}$ where it posts and generates conversation about social and political issues it deems significant. The party manifesto dedicates a section to young people. The content was derived from a youth vote survey coordinated by SODELPA Youth (Swami 2014). The party fielded some young candidates, one of whom, Mosese Bulitavu, is a current parliamentarian.

3 The 17 September elections were contested between seven political parties and two independent candidates, Umesh Chand and Roshika Deo.

4 For a detailed view of SODELPA Youth activities see www.facebook.com/sodelpayouth. 
Newer parties, such as the PDP and One Fiji Party (OFP), also appealed to young people during the build-up to the elections. The PDP president, Lynda Tabuya, who self-identified as a young person, labelled her party as offering a 'new brand of politics', particularly for women, young people and minority groups (Doviverata 2014). The PDP, in supporting young people's direct involvement in the party, had them represented in its management board and also had a mandated 30 per cent representation of women and young people on its branch committees. OFP, led by an articulate lawyer and young aspiring politician, Filimoni Vosarogo, released thematic social contracts or manifestos, one of which focused specifically on 'igniting young people'. ${ }^{5}$ The influence of OFP on young people is unknown; however, their policies proposed to support the future participation of young people through life skills training and the convening of a Youth Parliament, a popular structure for youth deliberation and debate in the past.

'Be the Change Campaign', the movement behind independent candidate Roshika Deo, was the only political entity that ran a youthled and youth-focused election campaign. Roshika Deo mobilised her supporters predominantly via political discussions on Facebook and, in the lead-up to the elections, organised pocket meetings. Limited funding hindered her goal of visiting as many geographical locations as possible. 'Be the Change' ran a successful campaign influencing and including young people in its membership drives, community visits and pocket meetings (Gibson 2014a). Unlike political parties, Roshika Deo concentrated on developing young people's political consciousness and addressing structural barriers like patriarchy, ageism and gender inequality. In Fiji, this campaign approach, although necessary, is up against well-resourced parties campaigning on addressing developmental issues and providing for a secure future.

FijiFirst (FF), the party of the incumbent Bainimarama Government, which had governed Fiji since 2006, did not appear to have specific policies targeted at young people. Instead, it employed the discourse of inclusivity, hosting 'family fun days' in Fiji's main centres and advertising its pragmatic developmental approach during the campaign period (Tolley 2014). The rhetoric of equal citizenry and developmental

5 For more details on One Fiji Party's manifesto see www.onefiji.org.fj/. 
assistance in the form of infrastructure development, free schooling and school bus fares, scholarships and subsidised electricity and water won favour with adults and young people alike. ${ }^{6}$ For young people concerned about completing school and finding employment, FijiFirst offered an element of stability and continuity, even if their track record of adherence to democratic principles was questionable. It could be argued that the reduction of the voting age to 18 years was a calculated decision, given the Bainimarama Government's appeal for a new brand of politics and the many policies and forms of assistance that directly impacted on first-time voters. Whilst the influence of FF on young people is real, it is imperative that young people are supported as active citizens and not used as a political ploy in between elections and during the next elections.

\section{Civil society organisations and youth engagement}

CSOs also played a role in preparing and supporting young people's democratic participation. Local CSOs like the CCF, Fiji Women's Rights Movement (FWRM) and the Fiji Women's Crisis Centre (FWCC), which were critical of the government, banded together under the Fiji NGO Coalition for Human Rights. Despite working in a restrictive environment, these organisations persisted with their human rights and democratisation work in communities. Many young people became directly or indirectly involved in these activities.

The government's decision to commence constitutional consultations and eventually to hold elections was welcomed by CSOs. The CCF supported communities with constitutional consultation submissions and an awareness on the 2013 Constitution. The FWRM was instrumental in the formation of the Fiji Young Women's Forum (FYWF), ${ }^{7}$ which worked to help young women with minimal or no understanding of democracy realise their responsibility as citizens and what this means in practice. The FYWF hosted two forums

6 For details of FijiFirst's manifesto see fijifirst.com/our-manifesto/\#toggle-id-7.

7 The forum was co-convened by the FWRM, the Emerging Leaders Forum Alumni (ELFA), Generation Next (GenNext), the Young Women's Christian Association (YWCA) and the Diverse Voices for Action (DIVA). 
with an ensuing outcome statement and declaration, ${ }^{8}$ and produced a publication entitled 'My Guide to Voting'. The outcome statement, declaration and the guide to voting booklet addressed the passivity that characterised the spaces of young people's involvement. Through these activities, the FYWF critically connected its members to their lived realities and the importance of aligning this with the democratic structure and leadership the young women wish to see in post-election Fiji.

The United Nations Development Programme (UNDP), through its Strengthening Capacities for Peace and Development (CPAD) project, complemented the work of CSOs during the constitution consultation process. The CPAD project was intended to 'generate interest in the constitution making process and enhance understanding of why the constitution is important to the everyday lives of all Fijians' (Saune \& Murdock 2013, p. 3). The project provided assistance through funding and support of other capacity-building strategies that allowed communities to openly and safely discuss issues they wanted reflected in the Constitution. Of the 146 funding applications received, 114 groups and organisations received funding. A notable number of these were youth groups or organisations that worked with specific youth-based interest groups (Saune \& Murdock 2013).

The project found that despite the challenges of working with marginalised groups like women and young people, many organisations succeeded in developing participatory spaces specifically for them. As a result, many youth groups were able to make submissions on the Constitution, some using creative mediums. This exercise offered young people the opportunity to be meaningfully engaged and to understand the issues experienced in their communities (Saune \& Murdock 2013). This awareness was intended to assist young people make an informed choice at the polls.

8 For details of the outcome statement and declaration see www.fwrm.org.fj/index.php/news/ media-releases/2013/318-fiji-young-women-s-forum and www.fwrm.org.fj/index.php/news/mediareleases/2014/330-young-women-s-declaration. 


\section{The media and young voters}

The media, both traditional outlets and the Internet, were also active in the lead-up to the elections. Traditional media (radio, television and newspapers) continued to be the main sources of political information, a view supported by respondents in the CCF Youth Democratic Participation survey. The Internet is gaining popularity and as access increases many people, particularly the young, will opt for the Internet as their source of information. In the lead-up to the elections, social media was labelled the 'Fiji election battleground' (Round 2014b), because political parties and politicians took to social media as an alternative campaign strategy. Social media was used to address time and resource constraints as well as young people's lack of engagement in traditional party politics. Social media became particularly useful for young activists and politically conscious young people in an environment where the traditional media was restricted. Active political engagement on social media became the domain of urban, educated young people, perhaps those who needed the least convincing when it came to voting. The extent to which social media influenced the election outcome is unknown because it is highly likely that family and friends would have been influential, particularly for undecided young voters.

\section{Did the youth vote matter?}

In the lead-up to the 17 September elections, confident sentiments were expressed about young people's influence on the election outcomes. The May issue of the Republika magazine had the headline 'Fiji votes: youth hold the balance of power' on its cover. In its feature article, Kelvin Anthony, a youth activist, wrote, 'when the counting of votes is completed after Wednesday 17 September elections, a lot will hinge on the contributions of young people who form the majority of the voters' (2014, p. 17). Similar sentiments were echoed until the eve of the elections. Days away from the elections, academic Steven Ratuva asserted that young people's votes would decide the election outcomes (Wilson 2014). Did young people's votes actually decide the election outcomes? 
This question is difficult to answer because the elections office provided neither figures nor analysis on voting characteristics, apart from the total votes cast at polling stations and total votes attained by political parties, party candidates and independents. One observation was clear: young people were not voting for young candidates. As an example, independent candidate Roshika Deo, who ran an overwhelmingly youth-centred campaign, attracted only 1,005 votes, ${ }^{9}$ far fewer than the over 14,000 likes on her Facebook campaign page and the required minimum threshold for a seat in parliament. Whilst this demonstrated that virtual support does not necessarily translate into actual votes, it also showed that young people exist as a diverse group and thus voted accordingly.

In an election where young people's votes were the centre of discourse within government, non-government and media circles, exit polls would have been useful to offer indications of voter demographic characteristics. Available analysis of voter behaviour has been limited to understanding voting along ethnic lines (Ratuva 2014). The characteristics of votes by young people are subsumed within these analyses. Given the overwhelming support for FF, which campaigned mostly on development and 'bread and butter' issues, it is not difficult to suggest that the majority of young people voted on the basis of securing their well-being. This is fairly consistent with the results of the CCF Youth Democratic Participation survey, in which most of young people identified, in order of priority, employment (43 per cent), education ( 37 per cent) and transport ( 11 per cent) as issues that would influence their vote (Vakaoti 2014).

Ethnic analysis of voter behaviour in the elections is useful, and in the absence of comprehensive demographic voter behaviour information young people are easily included in this analytical frame. Whilst this approach reflects the government's position on doing away with ethnic compartmentalisation, it fails to give due consideration to young people and their priorities and preferences. If the pre-government rhetoric of doing away with 'old politicians and politics' should become reality, it could ensure that voting behaviour is transparent, particularly for understanding young people, whose generational influences

9 For detailed election results see the Supervisor of Elections report available at www.electionsfiji. gov.fj/. 
are markedly different from those of their parents and other elders. Despite this reality, a bigger challenge lies with sustaining democratic support for young people into the post-election period and beyond.

\section{Supporting active citizenship for young people}

Voting is just one way of demonstrating active participation. The challenge for Fiji lies in supporting democratic structures at every level of society that meaningfully include young people. Whilst there are many structural and historical barriers, Fiji's return to parliamentary democracy offers hope that Fijians are aware of the future they want. Young people will significantly contribute to building on this vision and must be accorded an equal opportunity and provision of resources to do so. Stakeholders are equally critical in this process.

\section{The role of government}

Whilst it is difficult to assess the government's role in supporting the democratic participation of young people before the elections, performing this role in the post-election period is critical. The Ministry of Youth and Sports has the necessary structure and geographical reach to achieve this. Perhaps what is required is a reorientation of its focus from one of futurity and governmentality to one that considers the diverse realities and needs of young people (Vakaoti 2012). A national youth conference like that which was held in June 2014 could be made an annual event. In addition, the Ministry should consider reintroducing a national youth parliament as a way of connecting potential young leaders to decision makers and structures that facilitate their work.

Government has at its disposal the education system, where active and democratic citizenship could be introduced into the curriculum. It is imperative that Fiji's young people understand the country's socioeconomic and political history in order to make critical and informed decisions about their future. Discussion on topics like voting and the Constitution should be introduced in both primary and secondary schools. Participants in the CCF Youth Democratic Participation survey suggested that the best way of receiving political 
information in the future would be through citizen education in schools. Doing this will ensure 'a seamless transition from learning about democracy to putting such knowledge into practice' by the time one is 18 years of age (Youth Citizenship Commission 2008, p. 17). Universities would be expected to continue with this tradition, though this would be somewhat challenging given the recent experience where the University of the South Pacific in the period following the December 2006 coup had political debates and free thinking restricted as a result of a 'culture of political convulsion' (Lal 2004; Vakaoti 2012). Given Fiji's return to 'democracy' and healthy competition between the three universities in Fiji, there is optimism that critical young minds will continue to be cultivated at these institutions.

\section{The role of political parties}

Historically, the involvement of young people in party politics has been minimal. Results of the CCF Youth Democratic Participation survey reflects this reality. Of the 201 young people who participated in the survey, 90 per cent stated that they did not belong to a political party. This could in part be explained by the absence of party politics since 2006 and to the historical tendency of political parties to exclude young people from party machinery and processes. Young people's involvement in youth wings of the now disbanded Alliance Party, the waning FLP and the rejuvenated NFP were often regarded as tokenistic. ${ }^{10}$

The test of young people's sustained involvement in political parties will be seen in the period between elections. Parties like the NFP, PDP and SODELPA should continue to support the representation of young people on their management board, ensuring that their interests are considered and discussed at the decision-making level. This might be a point for consideration by parties that currently do not have such representation. It is also important that there are clear pathways within political parties for young people who aspire to move beyond being mere members, campaigners and volunteers. Parties serve

10 There are isolated cases where youth wings have been meaningfully involved and influential. Prior to 2006, the FLP's National Council, comprising 42 members, included a youth representative (Pareti \& Frankel 2007). It is likely that a lone youth individual would have little influence on party deliberations and decisions (Vakaoti 2012). Lal (2010), writing about Jai Ram Reddy, alluded to the influence of the NFP Youth Wing in the removal of the party leader in the mid-1980s. 
as ideal breeding grounds for future election candidates, politicians and leaders. Senior party officials and leaders could act as mentors to support this process. The members of the young people's Fiji Youth for Democracy (FYD) movement echo similar sentiments:

FYD believes that political parties are crucial for the long-term development in transitioning societies like Fiji ... Without wellfunctioning parties, governments and legislatures will have little chance of representing the wider society in a meaningful and effective way. Parties form a bridge between government and society, both in the ways they translate society's demands into political ideas and programs and in the way they hold government to account on society's behalf. (Scoop 2014)

\section{The role of civil society organisations}

Between 2006 and 2014, CSOs provided the 'voice of reason' in an environment devoid of basic democratic activities and processes. This role should continue into the post-election period. It is encouraging that the FYWF organised its third forum in November 2014 to discuss lessons learned from young women's political participation during elections and strategise for effective ongoing lobbying of decision makers. It is likely that other CSOs have plans of this nature in place for the future. The role of CSOs in this area need to be supported because they are effective spaces where young people can pursue issue-based interests and have direct experiences of different aspects of democratic participation.

\section{Youth-led initiatives}

Fiji is beginning to see an increase in youth-led organisations, active in the areas of mental health, gender discrimination and the creative arts (Vakaoti 2012). The lead-up to the 17 September elections brought to the fore young political activists like Roshika Deo of 'Be the Change Campaign' and youth-led organisations like the FYWF. The FYD movement, another youth-led organisation, was established in early 
2013 by a group of youth activists. The focus of FYD has been to generate critical conversations around the constitutional development process and related democratic issues. ${ }^{11}$

A noticeable trend with youth activists and organisations is their use of social media. Whilst the use of social media appeals to technologically savvy young people, it also addresses issues related to limited funding and technical assistance required to support the work of these organisations. Alternatively, it could be just that as members of this generation young people find that social networking and social media better serve their purpose. The FYD, for instance, exists as a virtual organisation with an active Facebook page ${ }^{12}$ and Twitter account. ${ }^{13}$ Given that Internet penetration in Fiji stands at about 30 per cent, it is likely that the group is able to garner support only in areas with Internet accessibility, most certainly in urban areas. Whilst the confidence of these young people and their social media strategies ought to be noted, their connection to the wider youth audience is yet to be realised. As Fiji transitions into democracy and the media environment progressively becomes free, young people will perhaps be able to complement their virtual activism in bolder and more visible ways.

\section{Conclusion}

The elections brought a semblance of democracy to Fiji. The polls were declared to be credible by the Multinational Observer Group, a government was sworn in and parliament is back in session following an absence of seven-and-a-half years. Fiji has returned to the fold, reinvited into the Pacific Islands Forum and readmitted into the Commonwealth; and in November 2014 hosted the Indian Prime Minister, Narendra Modi, and the Chinese President, Xi Jinping. These visits and developments signal that Fiji is well on its transitional path to democracy.

11 In 2013, the FYD organised four panel discussions at the University of the South Pacific on the Constitution, democracy, reflections on the 26th anniversary of the first coup in 1987 and extractive industries and livelihoods.

12 See www.facebook.com/FijiYouthForDemocracy.

13 See twitter.com/FijiYouth. 
Whilst government institutions appear to be fully functioning and diplomatic relations have been re-established, the government must deliver on its promise of granting young people greater civil and political rights. It must ensure that it has mechanisms and structures in place to consolidate the different ways in which young people participate and become involved in politics. The government's policy of generating a knowledge-based society must also include supporting young citizens to develop the critical ability to relate their issues and circumstances to decision-making structures at both the local and national level. CSOs also play a significant role in this process and must be encouraged to enter into dialogue with relevant government departments to deliver this opportunity for young people.

Young people from the age of 18 years were accorded the right to vote in the elections. Political parties and CSOs were active in this process. Community-based organisations supported the voter registration and awareness and education process, whilst political parties engaged young people directly as campaigners and volunteers, as members of management committees and as election candidates. Apart from traditional political campaigning and pocket meetings, social media became a vital part of engaging young voters with Internet connectivity. The influence of social media on voters, let alone young voters, is variable. A knowledge gap exists in relation to the use of social media for active political engagement and influence in Fiji. An understanding of this would assist those intending to digitally engage young voters in the next elections.

Regardless of intentions and speculations about the reduction of the voting age, young voters as active citizens must not rest on their laurels. They should, both in their youth sub-groups and as a collective, hold the government accountable to its promise of inclusivity and equality. Engaging in this process will give a sense of purpose to their vote on 17 September. Their collective strength, perhaps missing in the 2014 elections, could possibly be realised in the 2018 elections. A government that ignores the concerns of Fiji's growing and engaged population of young people does so at its peril. 


\section{References}

Anthony, K 2014, 'Young Blood: Fiji's young people hold the key to the election result, but do they know and will they use it?' Republika, May issue.

Baines, M 2013, 'Fiji's PDP supportive of constitution - but wants to fix laws', Radio New Zealand International, 28 August. Viewed 20 November 2014 at www.radionz.co.nz/international/pacificnews/218895/fiji's-pdp-supportive-of-constitution-but-wants-tofix-flaws.

Doviverata, R 2014, 'Lynda Tabuya Up for the Task', Fiji Sun [Online], 5 May. Viewed 20 November 2014 at fijisun.com.fj/2014/05/05/ lynda-tabuya-up-for-the-task/.

Esser, F 2007, 'Comparing Young Voters' Political Engagement in the United States and Europe', American Behavioral Scientist, vol. 50, no. 9, pp. 1195-213.

Ewart, R 2014, 'Fiji's young people excited to be voting for the first time', Radio Australia, 16 September. Viewed 21 November 2014 at www.radioaustralia.net.au/international/radio/program/ pacific-beat/fijis-young-people-excited-to-be-voting-for-the-firsttime/1368559.

Fiji Government Online 2010, Announcement on the Constitutional Consultations Process. Viewed 25 August 2014 at www.\#ji. gov. \&/Media-Center/Speeches/PM-BAINIMARAMA- - A N N O U N C E M E N T- O N - T H E - C O N S T I T U T I O N A L CONSULTATIONS-PROCESS.aspx.

Fiji Government Online 2013, 'Fiji Country Statement on ICPD Programme of Action - Sixth Asia and Pacific Population Conference'. Viewed at 20 November 2014 at www.fiji.gov.fj/Media-Center/Speeches/FijiCountry-Statement-on-ICPD-Programme-of-Action.aspx.

Fiji Government Online 2014, 'Ministers urges youths in Ba to vote'. Viewed 16 November at www.fiji.gov.fj/Media-Center/PressReleases/MINISTERS-URGES-YOUTHS-IN-BA-TO-VOTE.aspx. 
Fiji One 2014, 'Youths to converge in Suva for conference', 19 November. Available from fijione.tv/youths-to-converge-in-suva-for-conference/.

Gibson 2014a, 'Youths join 'change' campaign', Fiji Times [Online], 21 April. Viewed 16 November 2014 at www.fijitimes.com/story. aspx?id=266230.

Gibson 2014b, 'Youths role vital in election', Fiji Times [Online], 16 June. Viewed 20 November 2014 at www.fijitimes.com/story. aspx?id=271581.

Lal, B 2004, 'Laucala Bay' in B Lal (ed.), Pacific Places, Pacific Histories, University of Hawaii Press, Honolulu.

Lal, B 2010, In the eye of the storm: Jai Ram Reddy and the politics of postcolonial Fiji, ANU E Press, Canberra.

Online Editor 2014, 'Fiji PM Bainimarama delivers his promise to the world', Pacific Islands News Association, 28 September. Viewed 20 November 2014 at www.pina.com. $\mathrm{fj} / \mathrm{p}=$ pacnews $\& \mathrm{~m}=$ read $\& \mathrm{o}=1545660808542882 \mathrm{f} 682 \mathrm{f} 626 \mathrm{c} 8834 \mathrm{~d}$.

Pareti, S and Fraenkel, J 2007, 'The strategic impasse: Mahendra Chaudhry and the Fiji Labour Party', in J Fraenkel and S Firth (eds.), From election to coup in Fiji: the 2006 campaign and its aftermath, Asia Pacific Press and ANU E Press, Canberra.

Radio New Zealand International 2014, 'Fiji elections deemed credible', Radio New Zealand International, 19 September. Viewed 20 November 2014 at www.radionz.co.nz/international/pacificnews/254975/fiji-elections-deemed-credible.

Ratuva, S 2014, 'A symbol of hope - reflections on the Fiji election', Pacific.Scoop, 17 October. Viewed 20 November 2014 at pacific. scoop.co.nz/2014/10/a-symbol-of-hope-reflections-on-the-fijielection/.

Round, S 2014a, 'Fiji Sodelpa pushes youth voter registration', Radio New Zealand International, 13 March. Viewed 16 November 2015 at www.radionz.co.nz/international/programmes/datelinepacific/ audio/2588748/fiji-sodelpa-pushes-youth-voter-registration. 
Round, S 2014b, 'Social media becomes Fiji election battleground', Radio New Zealand International, 25 March. Viewed 7 January 2015 at www.radionz.co.nz/international/programmes/datelinepacific/ audio/2590200/social-media-becomes-fiji-election-battleground.

Saune, N and Murdock, J 2013, Supporting Community Outreach for the Constitutional Development Process Project Report, UNDP, Suva.

Scoop 2014, 'Fiji Youth for Democracy critical over interim Regime', Scoop, 29 July. Viewed 16 November 2014 at www.scoop.co.nz/ stories/WO1307/S00644/fiji-youth-for-democracy-critical-overinterim-regime.htm.

Swami, N 2014, 'SODELPA's youth wing discusses manifesto', Fiji Times [Online], 27 July. Viewed 22 November 2014 at www. fijitimes.com/story.aspx?id=275543.

Tokalau, T 2014, 'People, parties trying to get the youth vote', Fiji Times, 17 February. Viewed 20 November 2014 at www. fijitimes.com/story.aspx?id=260226.

Tolley, P 2014, 'Fiji First stages big rally in Nausori', Radio New Zealand International. Viewed 20 November 2014 at www.radionz. co.nz/international/pacific-news/254512/fiji-first-stages-big-rallyin-nausori.

Vakaoti, P 2012, 'Mapping the landscape of young people's participation in Fiji', SSGM Discussion Paper 6, pp. 1-19.

Vakaoti, P, 2013 'Young people's participation in Fiji: Merits, challenges and the way forward', Asia Pacific Viewpoint, vol. 54, no. 1, pp. 77-90.

Vakaoti, P 2014, Young People and Democratic Participation in Fiji, Citizens Constitutional Forum, Suva.

Vukailagi, D 2014a, 'Youth ministry encourage first time voters', Fiji One, 28 April. Viewed 15 November 2014 at fijione.tv/youthministry-encourage-first-time-voters/.

Vukailagi, D 2014b, 'NFP urges youth to make their votes count', Fiji One, 26 July. Viewed 16 November 2014 at fijione.tv/nfp-urgesyouth-to-make-their-votes-count/. 
8. FIJI ELECTIONS AND THE YOUTH VOTE-TOKEN OR ACTIVE CITIZENSHIP?

Wilson, C 2014, 'Youth votes will decide elections: Ratuva', Fiji One, 7 September. Viewed 15 November 2014 at fijione.tv/youth-voteswill-decide-elections-ratuva/.

Youth Citizenship Commission 2008, Old enough to make a mark? Should the voting age be lowered to 16? Youth Citizenship Commission, London. 
This text is taken from The People Have Spoken: The 2014 Elections in Fiji, edited by Steven Ratuva and Stephanie Lawson, published 2016 by ANU Press, The Australian National University, Canberra, Australia. 